\title{
STUDI FENOMENOLOGI KONTEKS BUDAYA JAWA DAN PENGARUH ISLAM: SITUASI PSIKOLOGIS KELUARGA DALAM MEMBANGUN EMPATI PADA REMAJA
}

\author{
Destareni Belda Puspawuni Wewengkang ${ }^{1}$, Moordiningsih ${ }^{2}$ \\ Fakultas Psikologi Universitas Muhammadiyah Surakarta \\ desta_reni@yahoo.com¹, moordiningsih@ums.ac.id²
}

\begin{abstract}
A form of empathy in the Java community is the mutual cooperation and ewuhpekewuh. One of them is rewang or nyinom in celebration event neighbor or relative. Judging from the development of the current era as a teenager began to abandon cultural traditions or rewang nyinom. This phenomenological study aimed to understand and describe the psychological situation of the family in building empathy in adolescents (Javanese cultural context and the influence of Islam). Key informants in this study were parents who reside in Surakarta, Muslim and has a teenage son or daughter children aged 11-20 years. Data collected used open questionnaire and interview. Results showed that the psychological situation of the family in building empathy in adolescents (Javanese cultural context and the influence of Islam) can be concluded that families build empathy in young children by giving examples and guidance for children to want to care for others. Regarding the forms of empathy teenagers (Javanese cultural context and the influence of Islam) that arise when caring for others is help parents at home, to visit a sick friend and worked together in the environment around the house. The principle of Javanese culture and Islamic principles of empathy that is applied by the family home is in the family worked together to apply the principles, ojo rumongso iso but iso rumongso, andhap asor, wong nandur bakale ngunduh and tangan mengkurep luwih becik tinimbang tangan mlumah.
\end{abstract}

Keywords: Psychological situation of the family, empathy, Javanese culture, the influence of Islam

\begin{abstract}
Abstrak. Wujud empati pada masyarakat Jawa adalah dengan gotong-royong dan ewuhpekewuh. Salah satunya dengan rewang atau nyinom dalam acara hajatan tetangga atau saudara. Penelitian ini bertujuan untuk memahami dan mendeskripsikan situasi psikologis keluarga dalam membangun empati pada remaja (konteks budaya Jawa dan pengaruh Islam. Informan utama dalam penelitian ini adalah orang tua yang bertempat tinggal di Karesidenan Surakarta, beragama Islam dan memiliki anak putra atau putri remaja yang berusia 11-20 tahun. Pengambilan data dilakukan menggunakan kuesioner terbuka dan wawancara. Hasilnya keluarga membangun empati pada anak remaja dengan cara memberi contoh dan pengarahan agar anak mau peduli terhadap orang lain. Mengenai bentuk-bentuk empati remaja (konteks budaya Jawa dan pengaruh Islam) yang muncul ketika peduli terhadap orang lain yaitu membantu orangtua dirumah, menjenguk teman yang sakit dan bergotong-royong di lingkungan sekitar rumah. Prinsip Budaya Jawa dan Prinsip Islam tentang empati yang diterapkan oleh keluarga dirumah adalah dalam keluarga menerapkan prinsip bergotong-royong, ojo rumongso iso tapi iso rumongso, andhap asor, wong nandur bakale ngunduh dan tangan mengkurep luwih becik tinimbang tangan mlumah.
\end{abstract}

Kata kunci : Situasi psikologis keluarga, empati, budaya Jawa, pengaruh Islam

\section{PENDAHULUAN}

Empati merupakan respon afektif yang berasal dari pemahaman kondisi emosional orang lain, perasaan yang sama dengan apa yang dirasakan orang lain. Empati adalah alat integral untuk mengetahui dan berhubungan 
dengan orang lain dan menambah kualitas hidup dan kekayaan interaksi sosial. Empati memiliki peran penting pada perkembangan pemahaman sosial dan perilaku social positif dan berfungsi sebagai fondasi hubungan dan menjadi dasar koping dengan stress dan penyelesaian konflik (Barr dan Higgins, 2009).

Kebudayaan hidup orang Jawa tak luput dari kehidupan sosial dan budaya Jawa yang dilatarbelakangi oleh kebiasaan di masa lampau. Kebiasaan di masa lampau mengajarkan masyarakat untuk saling menghargai dan mengutamakan tata krama. Setiap anggota kelompok hendaknya dapat mengembangkan keutamaan-keutamaan seperti rasa belas kasihan, kebaikan hati, kemurahan hati, kemampuan ikut merasakan kegelisahan orang lain, rasa tanggung jawab sosial, keprihatinan terhadap sesama, belajar berkorban demi orang lain dan menghayati pengorbanan itu sebagai nilai yang tinggi, tolong-menolong dan saling membantu satu sama lain (Asep, 2010).

Wujud empati pada masyarakat Jawa adalah dengan gotong-royong dan ewuhpekewuh. Gotong-royong maksudnya adalah saling membantu dan melakukan pekerjaan demi kepentingan bersama tanpa adanya imbalan apapun. Salah satunya dengan rewang atau nyinom dalam acara hajatan tetangga atau saudara. Tradisi rewang atau membantu tetangga tentunya suatu kegiatan yang sangat positif terutama untuk masyarakat Indonesia khususnya di Jawa sendiri yang memang kental dengan budaya gotong-royongnya karena dengan rewang bisa saling bergotongroyong antara warga yang satu dengan yang lainnya tanpa membeda-bedakan sehingga menimbulkan rasa saling membutuhkan dan membentuk persatuan yang kuat. Tradisi rewang ini terbentuk karena adanya kesadaran untuk membantu dan menolong antar tetangga tanpa pamrih. Sehingga ketika ada tetangga yang punya hajatan maka tetangga yang lain juga akan membantu. Hal ini akan terjadi sebaliknya, ketika di suatu kampung ada yang enggan menolong tetangga maka dirinya akan dijauhi tetangga ketika sedang membutuhkan. Selain itu, bentuk empati lainnya adalah tepa slira yang memiliki arti kepedulian untuk merasakan dan membantu sebisanya orang yang menderita serta dapat mengendalikan dan menghadirkan rasa dalam komunikasi dengan orang lain.

Dilihat dari perkembangan jaman saat ini nilai empati pada remaja sudah mulai berkurang. Lingkungan tempat tinggal dan tempat bergaul sangat mempengaruhi merosotnya nilai empati. Lunturnya nilai empati pada remaja menyebabkan menurunnya nilai kepedulian dan tolongmenolong dalam kehidupan bermasyarakat. Remaja mulai meninggalkan kebudayaan seperti tidak menghargai orang yang lebih tua sampai yang paling terlihat adalah untuk membantu antar sesama misalnya di Jawa yaitu tradisi nyinom atau rewang. Menurunnya nilai-nilai empati tidak terlepas dari semakin canggih teknologi pada jaman sekarang yang membuat remaja lebih memilih melakukan hal-hal yang berhubungan dengan teknologi yang mudah dan cepat untuk memperoleh sesuatu sesuatu yang diinginkan. Seseorang ketika mempunyai acara hajatan akan lebih memilih untuk menyewa jasa catering dan menyewa gedung daripada harus membuat acara hajatan dirumah sendiri dan menyusahkan tetangga atau orang- orang terdekatnya dalam memasak.

Para orang tua mengajarkan kepada anaknya untuk menghargai dan menghormati orang lain. Anak dibiasakan untuk saling tolong menolong tanpa pamrih dan tidak 
membeda-bedakan satu dengan yang lainnya seperti dalam ajaran Islam yang mengajarkan tolong menolong setulus dan seikhlasnya agar bisa menjadi berkah. Misalnya anak diajarkan untuk berbagi dengan teman bermainnya, menolong teman yang sedang mengalami kesusahan atau membutuhkan bantuan. Hal tersebut hendaknya didukung dengan suasana yang membuat anak merasa nyaman dengan perbuatan yang dilakukannya sebagai bentuk keberhasilan orangtua dalam menanamkan nilai moral yang berbasis islami. Dalam membentuk situasi psikologis yang diharapkan adanya peran dari keluarga. Meskipun tidak secara khusus berfokus pada struktur keluarga tetapi mampu menyoroti pentingnya iklim emosional keluarga dalam menciptakan kesejahteraan psikologis pada remaja dengan dukungan interaksi yang diberikan keluarga.

Situasi psikologis yang kondusif di lingkungan tidak selamanya dapat terjadi sesuai dengan yang diharapkan. Dalam situasi psikologis yang kondusif, anggota keluarga mempersepsikan lingkungannya dengan keadaan yang dinamis, tenang, nyaman, damai, saling percaya, penuh kehangatan, dan terjadi interaksi yang aktif dalam relasi sosial antaranggota keluarga (Moordiningsih, Prastiti, dan Hertinjung, 2010).

Berdasarkan uraian di atas maka penulis tertarik untuk melakukan penelitian fenomenologi mengenai situasi psikologis keluarga dalam membangun empati pada remaja dalam konteks budaya jawa dan pengaruh Islam. Peneliti ingin mengetahui bagaimana situasi psikologis keluarga dalam membangun empati pada remaja.

Empati sebagai tanggapan afeksi seseorang terhadap suatu hal yang dialami orang lain seolah mengalami sendiri hal tersebut dan diwujudkan dengan bentuk menolong, menghibur, berbagi dan bekerja sama dengan orang lain (Walgito, 2002). Menurut Eileen dan Sylvina (dalam Taufik, 2000) empati adalah kegiatan berpikir individu mengenai rasa yang dihasilkan ketika berhubungan dengan orang lain. Sobur (2003) juga menambahkan pada dasarnya kemampuan empati merupakan peralatan antar pribadi yang sangat bermanfaat karena kemampuan empati adalah kemampuan untuk melihat dunia dari sudut pandang orang lain, kemampuan empati untuk menyelaraskan diri dengan yang mungkin dirasakan dan dipikirkan orang lain tentang suatu situasi betapapun berbedanya pandangan itu dengan pandangan seseorang.

Sumarni (2003) memaparkan dua komponen dalam empati yaitu komponen kognitif dan komponen afektif. Komponen kognitif difokuskan pada proses-proses intelektual untuk memahami perspektif orang laindengantepat.Sedangkankomponenafektif diartikan sebagai kecenderungan seseorang untuk memahami perasaan emosional orang lain. Kedua komponen tersebut mempunyai masing-masing dua aspek. Dalam komponen kognitif yaitu aspek perpective taking dan fantasy, dan dalam komponen afektif, yaitu aspek empaty corcern, personal distress. Dari keempat aspek tersebut, Baron \& Byrne (1997) menambahkan satu aspek yang merupakan komponen afektif yaitu feeling sympathetic.

Gunarsa (1991) menyatakan bahwa kemampuan berempati individu banyak dipengaruhi oleh derajat kematangan seseorang. Derajat kematangan merupakan besarnya kemampuan seseorang dalam memandang suatu hal secara proporsional, boleh jadi seseorang yang usianya lebih muda mempunyai derajat kematangan yang lebih tinggi dibandingkan dengan seseorang 
yang usianya lebih tua, sehingga boleh jadi seseorang yang lebih muda mampu berempati dibandingkan dengan orang yang lebih tua.

Dalam kajian Islam contoh dari empati terdapat dalam H.R. Bukhari dan Muslim yang berbunyi "Perumpamaan kaum mukmin dalam kasih sayang dan belas kasih serta cinta adalah seperti satu tubuh jika satu bagian anggota tubuh sakit maka akan merasa sakit seluruh tubuh dengan tidak bisa tidur dan merasa demam." Hal ini dimaksudkan bahwa setiap kaum muslim seharusnya memiliki ikatan emosional yang kuat sehingga perilaku yang muncul tidak hanya berakhir secara formalitas sebatas membantu korban bencana alam, dan menolong orang lain yang terkena musibah. Namun terlebih dahulu didasari karena rasa persaudaraan yang menumbuhkan perasaan saling merasakan apa yang dirasakan saudara sesama muslim yang lain. Selain itu bentuk empati dalam Islam juga tertuang dalam ajaran berpuasa. Allah berkehendak memberikan persamaan di antara hamba-hamba-Nya agar setiap manusia bisa merasakan kepedihan lapar dan rasa sakitnya, merendahkan hatinya dihadapan orang lemah, dan mengasihi orang lapar. Dalam Al-Quran, kelanjutan bentuk empati salah satunya dapat berupa perilaku menolong. Hal ini seperti dilukiskan dalam surat Al-Maidah ayat 2 yang artinya :'Dan tolong-menolonglah kamu dalam (mengerjakan) kebajikan dan takwa".

Keluarga adalah pusat pendidikan pertama dan utama. Dikatakan sebagai pusat pendidikan pertama, karena anak mulai dikenalkan dengan nilai-nilai baik dan buruk tentu ukurannya adalah norma-norma Islam yang pertama kali dari kedua orangtuanya atau orang-orang terdekat, yang berada dalam lingkungan keluarganya. Sedang dikatakan sebagai pusat pendidikan yang utama, karena yang lebih bertanggung jawab atas pendidikan peserta didik adalah orangtua mereka, meski mereka sudah mengenal masyarakat, masjid maupun sekolah (Sudarno, 2010).

Situasi psikologis keluarga merupakan situasi yang kondusif dapat dimaknai bahwa situasi psikologis yang terjadi dalam kelompok adalah dalam keadaan dinamis, tenang, nyaman, damai, saling percaya, serta penuh kehangatan dalam relasi sosial antar anggota kelompok (Moordiningsih, Prastiti, dan Hertinjung, 2010). Dalam keluarga Jawa juga mengembangkan rasa belas kasihan, kebaikan hati, kemurahan hati, kemampuan untuk ikut merasakan kegelisahan orang lain, rasa tanggung jawab sosial, dan keprihatinan terhadap sesama.

Wibawa (2012) mengemukakan bahwa dalam bahasa dan sastra Jawa terkandung tata nilai kehidupan Jawa seperti norma, keyakinan, kebiasaan, konsepsi, dan simbol-simbol yang hidup dan berkembang dalam masyarakat Jawa, toleransi, kasih sayang, tepaslira, gotong royong, andhap asor, kemanusiaan, nilai hormat, tahu berterimakasih, dan lainnya. Sikap andhap ashor berarti rendah hati yang mengandung makna tidak mau menonjolkan diri, meskipun sebenarnya memiliki kemampuan.

\section{METODE PENELITIAN}

Penelitian ini menggunakan metode kualitatif fenomenologi dengan alat pengumpul data kuesioner terbuka dan wawancara. Informan dalam penelitian ini ditetapkan berdasarkan orang tua yang bertempat tinggal di Karesidenan Surakarta, beragama Islam dan memiliki anak remaja putra atau putri yang berusia 11-20 tahun. Pada penelitian ini, peneliti menambahkan informan pendukung, yaitu anak remaja dari orangtua. Kuesioner terbuka dibuat berdasarkan tujuan dan pertanyaan penelitian yang dibagikan kepada informan utama. 
Sedangkan wawancara pada penelitian kali ini dilakukan kepada 10 informan pendukung atau orang tua subjek dengan tujuan untuk menambah referensi dalam hasil penelitian.

\section{HASIL DAN PEMBAHASAN}

Jika ditinjau dari situasi psikologis keluarga dalam membangun empati pada remaja konteks budaya Jawa dan pengaruh Islam maka diperoleh hasil penelitian yang menggunakan kuesioner diketahui bahwa prosentase tertinggi untuk frekuensi perasaan informan ketika berkumpul bersama keluarga dirumah adalah merasa bahagia. Melihat dari uraian tersebut dapat disimpulkan bahwa berkumpul bersama keluarga merupakan kebahagiaan bagi setiap keluarga. Wijayanti \& Nurwiyanti (2010) yang menyatakan bahwa kebersamaan seluruh keluarga merupakan salah satu wujud bentuk kebahagiaan yang ada didalam suatu keluarga. Dalam konteks budaya Jawa peribahasa "mangan ora mangan nek kumpul" juga mencerminkan bahwa budaya Jawa selalu ingin berkumpul bersama keluarga maupun lingkungan sosialnya. Peribahasa Jawa tersebut memberikan gambaran bahwasanya apapun keadaan yang sedang dijalani atau apapun masalah yang sedang dihadapi bukanlah merupakan suatu penghalang untuk berkumpul, berinteraksi, atau berkomunikasi satu sama lain antar anggota keluarga.

Setiap keluarga mendambakan keluarga ideal yang dilihat berdasarkan hasil penelitian menggunakan metode kuesioner informan membentuk dan mewujudkan keluarga yang sejahtera (sakinah, mawadah, warahmah) adalah dengan mentaati ajaran agama, karena didalam islam orangtua mempunyai tugas mendidik dan mengajarkan akhlak yang mulia kepada anak sesuai perintah Allah. Selain itu dalam keluarga Jawa selalu mengutamakan nilai-nilai moral yang berpegang pada ajaran kebudayaan terutama nilai kepedulian. Hal ini terlihat dari pernyataan Asep (2010) yang menyatakan bahwa setiap anggota keluarga hendaknya dapat mengembangkan keutamaan- keutamaan seperti rasa belas kasihan, kebaikan hati, kemurahan hati, kemampuan ikut merasakan kegelisahan orang lain, rasa tanggung jawab sosial, keprihatinan terhadap sesama, belajar berkorban demi orang lain dan menghayati pengorbanan itu sebagai nilai yang tinggi. Selanjutnya melalui pengajaran yang diberikan orangtua kepada anak mengandung nilai kepedulian terhadap sesama. Hal tersebut terlihat dari frekuensi informan memberi contoh kepada anak agar peduli terhadap orang lain dengan cara tolong-menolong.

Pemberian contoh dari orangtua untuk menolong sesama merupakan wujud pembentukan perilaku anak dalam keluarga yang ditentukan oleh sikap dan perilaku orangtua yang dilihat dan diamati anak dalam kehidupan sehari-hari. Dalam Al- Quran Qs. Al-maidah: 02 yang mengandung arti bahwa tolong-menolong merupakan bentuk kepedulian seseorang dalam mengerjakan kebajikan dan taqwa. Selain tolongmenolong cara lain yang diajarkan tentang kepedulian adalah bersedekah kepada orang lain. Bersedekah merupakan pemberian dari seorang muslim secara sukarela dan ikhlas tanpa dibatasi oleh waktu dan jumlah. Dari segi bentuknya sedekah sesungguhnya tidak dibatasi pemberian dalam bentuk uang, tetapi sejumlah amal kebaikan yang dilakukan seorang muslim sebagai sarana beribadah. Hal ini tergambar dalam Al-Quran Qs. A1 Baqoroh ayat 261 yang mengandung makna bahwa nafkah yang dikeluarkan oleh manusia akan dilipat gandakan Allah nantinya.

Pada kehidupan sehari-hari anak dibimbing dan diarahkan untuk mampu berempati pada situasi/keadaan yang 
membuat anak terbiasa dengan sesuatu yang diperhatikan dan diamati oleh anak. Hal ini sesuai dengan hasil wawancara dari beberapa subjek yang menyatakan bahwa anak mampu peduli terhadap lingkungan sekitarnya ketika situasi/keadaan dirumah sedang sibuk dan membutuhkan bantuan. Anak diberikan contoh untuk mampu berempati pada keluarganya dengan cara membantu anggota keluarga yang sedang membutuhkan bantuan seperti ketika orangtua sedang bekerja anak dibiasakan untuk ikut membantu dalam mengerjakan pekerjaan rumah. Kebiasaan tersebut berawal dari ajaran orangtua sebagai perintah kepada anak yang harus dipatuhi dan lama kelamaan menjadikan hal tersebut kewajiban yang harus dilakukan oleh anak. Anak dibiasakan untuk membantu pekerjaan rumah agar mengurangi beban anggota keluarga dirumah. Sehingga tanpa disadari pembentukan empati berawal dari kebiasaan yang diajarkan orangtua. Hal ini merupakan gambaran dari konsep iklim keluarga sebagai pola perilaku/sikap yang dilakukan berulangulang dan perasaan yang mencirikan kehidupan dalam sebuah keluarga (Isaksen, Lauer, Ekvall, \& Britz, dalam Bartlett, 2011).

Hasil penelitian ini sejalan dengan pernyataan yang dikemukakan oleh Sudarno (2010)yaitukeluarga sebagai pusat pendidikan pertama dan utama. Dikatakan sebagai pusat pendidikan pertama, karena anak mulai dikenalkan dengan nilai-nilai baik dan buruk tentu ukurannya adalah norma-norma Islam yang pertama kali dari kedua orangtuanya atau orang-orang terdekat, yang berada dalam lingkungan keluarganya. Sedang dikatakan sebagai pusat pendidikan yang utama, karena yang lebih bertanggung jawab atas pendidikan peserta didik adalah orangtua mereka, meski mereka sudah mengenal masyarakat, masjid maupun sekolah.
Selain pembiasaan, situasi/keadaan yang digunakaan orangtua untuk membentuk empati pada anak yakni melalui cerita antara orangtua dan anak mengenai kesusahan yang dialami oleh orang lain. Dari hasil wawancara mengungkapkan bahwa orangtua mengajarkan empati kepada anak pada saat keluarga duduk bersantai dengan menceritakan tentang tetangga yang mengalami kesusahan dan seolah-olah anak mengalami hal tersebut. Dalam kisah tersebut orangtua menanamkan pada anak bahwa peristiwa atau keadaan tersebut mungkin dapat menimpa diri anak. Oleh karena itu orangtua mengajarkan kepada anak untuk selalu mencoba memperhatikan lingkungan sekitar yang sedang mengalami kesusahan sehingga anak mampu mewujudkan kepeduliannya langsung kedalam bentuk perilaku. Menurut Wang (2003), komponen empati dari komunikatif adalah ekspresi dari pikiran empati (intellectual emphaty) dan perasaan empati (empathic emotions) terhadap orang lain yang dapat diekspresikan melalui kata-kata dan perbuatan langsung.

Hal tersebut sesuai dengan teori Ali Muhtadi (2009) yang menyatakan bahwa individu yang mempunyai rasa empati yang sudah cukup tinggi biasanya akan ikut terhanyut dalam suatu cerita dan tidak jarang mampu merasa sedih dan menangis. Pada saat situasi tersebut terjadi persepsi tentang hal yang dirasakan oleh orang lain dan menanamkan pentingnya empati pada diri anak.

Berdasarkan perilaku dan kebiasaan yang dilakukan orangtua dalam mengajarkan anak untuk peduli terhadap sesama, memunculkan beberapa tindakan yang kemudian diaplikasikan anak dalam kehidupannya bermasyarakat seperti peduli terhadap keluarga, teman sebaya dan masyarakat 
sekitar. Dari hasil penelitian menggunakan kuesioner diketahui prosentase tertinggi untuk tindakan yang dilakukan anak ketika peduli terhadap orang lain adalah membantu orangorang di sekitarnya. Hal ini senada dengan hasil penelitian menggunakan wawancara kepada orangtua yang menyatakan bahwa tindakan yang dilakukan ketika anak peduli terhadap orang lain dengan membantu keluarga dirumah untuk memasak, mencuci, dan menjaga adik serta membantu teman yang sedang kesusahan disekolah dan membantu tetangga ketika ada acara disuruh membantu membawa minuman, makanan, dan makanan ringan. Hal tersebut sesuai dengan hasil wawancara terhadap anak yang menyatakan bentuk kepeduliannya ketika peduli terhadap orang lain adalah membantu keluarga dirumah untuk memasak, menyapu halaman, mencuci piring dan menjaga adik dirumah. Kepedulian lain yang ditunjukan anak remaja ketika peduli terhadap lingkungan sekitar seperti membagikan sedikit bekal makanan kepada teman disekolah, serta bentuk kepedulian yang ditunjukan kepada tetangganya adalah menjenguk tetangga yang sakit bersama-sama warga daerah rumah, bergotong- royong dan membantu tetangga yang membutuhkan bantuan yang sering dikenal dengan sebutan nyinom/rewang, serta memberi uang kepada pengemis ataupun pengamen yang dijumpainya.

Hal ini sesuai dengan teori yang dikemukakan oleh Walgito (2002) yaitu empati sebagai tanggapan afeksi seseorang terhadap suatu hal yang dialami orang lain seolah mengalami sendiri hal tersebut dan diwujudkan dengan bentuk menolong, menghibur, berbagi dan bekerja sama dengan orang lain. Dalam ajaran Islam sendiri menuntut masyarakat untuk saling membantu dan saling memperhatikan satu sama lain agar dapat membangun tanggung jawab sosial (Sayyid, 1997).

Dalam kebudayaan Jawa kepedulian tersebut terlihat dari wujud empati pada masyarakat Jawa dengan bergotongroyong yang artinya saling membantu dan melakukan pekerjaan demi kepentingan bersama tanpa adanya imbalan apapun. Salah satunya dengan rewang atau nyinom dalam acara hajatan tetangga atau saudara. Tradisi rewang atau membantu tetangga tentunya suatu kegiatan yang sangat positif terutama untuk masyarakat Indonesia khususnya di Jawa sendiri yang memang kental dengan budaya gotong-royongnya karena dengan rewang bisa saling bergotong-royong antara warga yang satu dengan yang lainnya tanpa membeda-bedakan sehingga menimbulkan rasa saling membutuhkan dan membentuk persatuan yang kuat. Tradisi rewang ini terbentuk karena adanya kesadaran untuk membantu dan menolong antar tetangga tanpa pamrih. Sehingga ketika ada tetangga yang punya hajatan maka tetangga yang lain juga akan membantu (Wibawa, 2010).

Dalam membangun empati pada remaja, keluarga memiliki peran penting dalam mengajarkan dan menumbuh kembangkan kepedulian anak terhadap orang lain. Pada masyarakat Jawa sudah ditanamkan budi pekerti kehidupan sebagai masyarakat sosial yang tidak bisa hidup sendiri tanpa bantuan orang lain. Saling membantu dan melakukan pekerjaan demi kepentingan bersama tanpa adanya imbalan dan tanpa membeda- bedakan sehingga menimbulkan rasa saling membutuhkan dan membentuk persatuan yang kuat merupakan gambaran dari masyarakat Jawa.

Berdasarkan hasil penelitian menggunakan kuesioner dapat diketahui prinsip budaya Jawa yang diterapkan di 
rumah agar anak mau peduli terhadap orang lain adalah gotong royong. Konsep gotong royong juga dapat dimaknai dalam konteks pemberdayaan masyarakat karena hal tersebut menjadi modal sosial untuk membentuk kekuatan kekeluargaan di lingkungan dalam mewujudkan kesejahteraan. Koentjaraningrat (1998) menyatakan bahwa nilai gotong royong dalam sistem budaya orang Jawa mengandung konsep yaitu manusia hidup di dunia saling membutuhkan oranglain. Dengan demikian, manusia pada hakekatnya tergantung dalam kehidupannya kepada sesamanya. Karena itu seseorang selalu berusaha untuk sedapat mungkin memelihara hubungan baik dengan orang lain sehingga menganggap seluruh manusia diciptakan sama dan berusaha untuk bisa mengahargai satu sama lainnya.

Selain itu prinsip budaya Jawa dipegang dan diajarkan kepada anak untuk mampu berempati kepada orang lain yakni ojo rumangsa bisa nanging bisa rumangsa yang memiliki arti bahwa sebagai manusia janganlah selalu merasa bisa, tetapi bisalah untuk merasa. Pada kehidupan masyarakat Jawa, banyak ditemukan nasehat agar anak remaja tetap memiliki pribadi yang rendah hati dan tidak menganggap rendah pihak lain. Dalam ajaran Jawa seseorang lebih ditekankan untuk dapat melakukan koreksi sehingga tidak terdorong untuk meremehkan orang lain. Seseorang tidak dibenarkan untuk menonjolkan dirinya sendiri karena dalam hal ini seseorang lebih ditekankan untuk menyadari bahwa dirinya juga memiliki keterbatasan. Hal ini sesuai dengan teori Koentjaraningrat (1998) yang menyatakan bahwa rumongso iso adalah rasa untuk lebih melihat kedalam diri sendiri terlebih dahulu, membesarkan rasa introspeksi diri, menguatkan pondasi hati, dan melihat orangorang disekitar yang lebih membutuhkan sebagai bentuk silaturahmi.
Ditemukan juga prinsip budaya jawa yang sering dikenal dengan sikap andhap ashor atau rendah hati yang mengandung makna tidak mau menonjolkan diri, meskipun sebenarnya memiliki kemampuan. Masyarakat Jawa sangat mengutamakan sikap andhap ashor dalam menjalin hubungan dengan orang lain dan menganggap setiap celaan dari orang lain sebagai sarana mawas diri sehingga mampu mengadakan perbaikan. Hal ini sesuai dengan teori Wibawa (2010) yang menyatakan bahwa masyarakat Jawa sangat mengutamakan sikap andhap ashor dalam menjalin hubungan dengan orang lain dan menganggap setiap celaan dari orang lain sebagai sarana mawas diri sehingga mampu mengadakan perbaikan.

Dari hasil penelitian menggunakan metode wawancara didapatkan prinsip Jawa untuk mampu berempati adalah tangan mengkurep luwih becik katimbang tangan mlumah. Pengertian dari istilah tangan mengkurep adalah memberi bantuan atau menolong orang lain yang membutuhkan semampunya tanpa mengharapkan balasan. Hal ini telah menjadi kebiasaan bagi masyarakat Jawa yang mempercayai bahwa banyak memberi maka akan banyak rejeki seperti dalam peribahasa jawa yang dikenal dengan wong nandur bakal ngunduh, dimana yang artinya adalah siapa yang menanam kebaikan makan akan menuai kebaikan pula (Asep, 2010). Dari pernyataan orangtua pada saat wawancara, orangtua selalu mengajarkan anaknya untuk selalu bersedekah agar dimudahkan mendapatkan rejeki untuk memenuhi kebutuhannya.

Sedangkan tangan yang mlumah atau mengadah menggambarkan orang yang selalu minta atau tidak mau bekerja sehingga hanya mengharapkan pertolongan dari orang lain. Orangtua pada masyarakat Jawa mengajarkan hal tersebut kepada anaknya 
agar dapat memenuhi kebutuhan sendiri dan tidak mengharapkan orang lain.

Selanjutnya dari prosentase tertinggi prinsip agama Islam yang diterapkan di rumah agar anak bisa peduli terhadap orang lain adalah beribadah. Beribadah dalam masyarakat Jawa merupakan bentuk ketaqwaan mereka kepada Allah maha pencipta langit dan bumi. Beribadah dalam masyarakat Jawa terlihat dari hasil kuisioner yang diungkap kepada orangtua dan anak menyatakan bahwa didalam keluarga bentuk kepedulian Islam yang diajarkan dirumah adalah sholat, berpuasa, dan bersedekah.

Dari hasil penelitian yang dilakukan dengan metode wawancara bentuk kepedulian yang dilakukan setelah menjalankan sholat adalah mendoakan orang lain yang sedang tertimba musibah. Dengan bentuk mendoakan tersebut orangtua mengajarkan anak bentuk empati yang terkandung dalam ajaran sholat. Hal ini sesuai dengan hadits yang terkandung dalam HR. Muslim yang menjelaskan semua muslim itu satu tubuh, apabila muslim lain mengalami kesusahan maka muslim yang lainnya akan merasakan hal yang sama. Selain itu bentuk kepedulian dalam prinsip Islam yang diajarkan keluarga Jawa adalah berpuasa. Berpuasa diajarkan sejak anak berusia dini, harapan orangtua dari puasa tersebut agar anak mampu menahan hawa nafsu dan mampu merasakan apa yang dirasakan oleh orang yang kurang mampu. Hal ini sesuai dengan teori Sayyid (1997) yang menyatakan bahwa islam menghimbau umatnya untuk berpuasa agar dapat ikut merasakan penderitaan orang lain. Melalui puasa tersebut, anak remaja berlatih untuk berempati terhadap penderitaan yang dialami orang lain yang mengalami kelaparan dan kehausan. Setelah merasakan penderitaan orang lain, orangtu mengajarkan anak remaja untuk melakukan sedekah semampunya kepada orang yang membutuhkan. Dalam ajaran Islam manusia melakukan bentuk kepeduliannya dengan berzakat atau bersedekah. Selain mensucikan harta, berzakat juga bermanfaat untuk membantu orang lain sehingga dapat meringankan beban penderitaan orang lain. Sedekah merupakan pemberian dari seorang muslim secara sukarela dan ikhlas tanpa dibatasi waktu dan jumlah. Dari segi bentuknya, sedekah sesungguhnya tidak dibatasi pemberian dalam bentuk uang, tetapi sejumlah amal kebaikan yang dilakukan seorang muslim sebagai sarana beribadah. Hal tersebut sesuai dengan Alquran dalam Al-Baqarah ayat 261 yang memiliki arti bahwa pahala dari nafkah yang dikeluarkan kepada oranglain akan dilipat gandakan oleh Allah SWT.

\section{SIMPULAN}

Mengenai situasi psikologis keluarga dalam membangun empati pada remaja (konteks budaya Jawa dan pengaruh Islam) dapat disimpulkan bahwa keluarga mengajarkan anak untuk mentaati ajaran agama seperti menjalankan sholat 5 waktu, mengaji, berpuasa dan sedekah. Dalam mengajarkan anak remaja berempati, orangtua memberikan contoh perilaku langsung kepada anak dengan menolong orang yang membutuhkan bantuan dan menceritakan musibah yang dialami orang lain. Melalui perilaku yang diamati dan dilihat anak, hal tersebut menjadikan kebiasaan anak remaja untuk berempati kepada orang lain.

Bentuk-bentuk empati remaja (konteks budaya Jawa dan pengaruh Islam) yang muncul ketika peduli terhadap keluarganya yaitu membantu orangtua di rumah ketika membutuhkan bantuan seperti memasak, mencuci, membersihkan rumah dan menjaga adik. Hal lain yang ditunjukan anak remaja ketika peduli terhadap temannya adalah 
membagi makanan, menjenguk teman yang sakit dan mengajak teman berangkat sekolah bersama. Sedangkan untuk kepedulian anak remaja ketika mampu peduli terhadap tetangga sekitar rumahnya adalah membantu tetangga yang sedang memiliki acara dan bergotong royong di lingkungan sekitar rumah.

Prinsip budaya Jawa dan prinsip budaya Islam tentang empati yang diterapkan oleh keluarga dirumah adalah dalam keluarga menerapkan prinsip bergotong-royong, ojo rumongso iso tapi iso rumongso, andhap asor, wong nandur bakale ngunduh, dan tangan mengkurep luwih becik tinimbang tangan mlumah. Sedangkan prinsip Islam yang diterapkan dirumah untuk peduli terhadap orang lain adalah dengan cara menjalankan sholat untuk mendoakan orang yang terkena musibah, berpuasa dan bersedekah.
Penelitian ini mempunyai keterbatasan, salah satunya adalah pada kuesioner yang digunakan untuk mengambil data. Aspek yang ditanyakan kurang tajam dalam menggali informasi tentang pembentukan empati. Maka peneliti selanjutnya dapat memperbaiki kualitas kuesioner dan panduan in deep interview yang akan digunakan untuk melakukan penelitian.

Saran bagi orang tua dan keluarga diharapkan mampu berperan serta dalam membangun terbentuknya kepedulian anak kepada orang lain sesuai dengan prinsip budaya Jawa dan ajaran Islam, yaitu agar mampu memberikan contoh dan pengarahan yang lebih kepada anak agar mampu peduli terhadap orang lain yang ada disekitarnya.

\section{DAFTAR PUSTAKA}

Ali, (2009) Pengembangan empati anak sebagai dasar pendidikan moral. Jurnal Psikologi. 10(2). 124-132

Asep, R. (2010). Falsafah hidup jawa. Yogyakarta : Logung Pustaka.

Barr, J. J., \& Higgins, A. (2009). How Adolescent Empathy and Prosocial Behavior Change In The Context Of School Culture A Two-Year Longitudinal Study. Adolescence. 44(176)/ 751-772

Baron, R. \& Byrne, D. (1997). Social Psychology. 8th Edition. Massachussets: Allyn and Bacon, Inc.

Bicrhoff, H. W. (2002). Prosocial behavior. New York: Psychology Press

Ridley, M., \& Lingle. (1996). Masalah-masalah evolusi. Universitas Indonesia.

Saptono. (2013). Memudarnya Tradisi Rewang di Jawa. Diunduh melalui www.Solopos.com pada tanggal 12 April 2014 pukul 12:40

Sayyid, M. (1997). Mukhtarul ahadist annabawiyyah. Surabaya: Hidayah.

Sobur, A. (2003). Psikologi umum. Bandung: Pustaka Setia.

Sudarno. (2010). Studi islam 3. Jakarta: Pustaka Setia

Sumarni, E. (2003). Hubungan Antara Intensi Prososial Dan Kemampuan Berempati Dengan Kepuasan Kerja. Skripsi. (Tidak Diterbitkan). Fakultas Psikologi. Universitas Muhammadyah Surakarta 
Taufik, I. W. (2000). Hubungan Empati Dengan Intensi Prososial pada Siswa-Siswi Muhammadiyah Mataram. Skripsi (tidak diterbitkan). Surakarta: Fakultas Psikologi. Universitas Muhammadyah Surakarta

Walgito, B. (2002). Suatu pengantar psikologi sosial. Yogyakarta: Andi Offset.

Wibawa, S. (2011). Bahasa dan Sastra Jawa sebagai Sumber Pendidikan Karakter dan Implementasinya dalam Pendidikan. Makalah. Kongres Bahasa Jawa Kelima 27-30 Nopember 2011.

Wijayanti, H., \& Nurwiantri, F. (2010). Kekuatan karakter dan kebahagiaan pada suku jawa. Jurnal Psikologi. 3(2). 114-122 